\title{
Electrical characteristic of photovoltaic thermal collector with water-multiwalled carbon nanotube nanofluid flow
}

\author{
Nur Farhana Mohd Razali, Ahmad Fudholi, Mohd Hafidz Ruslan, Kamaruzzaman Sopian \\ Solar Energy Research Institute, Universiti Kebangsaan Malaysia, \\ 43600 Bangi Selangor, Malaysia
}

\begin{tabular}{l}
\hline Article Info \\
\hline Article history: \\
Received May 23, 2018 \\
Revised Jun 30, 2018 \\
Accepted Jul 20, 2018 \\
\hline
\end{tabular}

Keywords:

Efficiency

Fill factor

I curve

MWCNT

Power

PVT

V curve

\begin{abstract}
Photovoltaic thermal (PVT) studies show promising results from utilizing waste heat under the PV module. Heat removal is essentially the base of a PVT collector. The heat absorption from the back of the PV module used for different purposes. Solar energy being collected are mostly turned into heat and needs to be extracted to maintain PV's efficiency. The PVT collector works similar to a flat plate solar collector, except that the short wavelengths are converted into electricity and the remaining wavelengths into useful heat. The heat collected is also at a lower magnitude than collected by solar thermal collectors. This study present the experimental investigation to improve the efficiency of PVT collector with and without Multiwalled Carbon Nanotube (MWCNT) nanofluid using spiral rectangular tube absorber as cooling. The electrical characteristic of PVT collector are represented by plotting power $(\mathrm{P})$-voltage $(\mathrm{V})$, current $(\mathrm{I})$-voltage $(\mathrm{V})$ curves. The results shows the power generated will increase with the increasing of solar radiation, and efficiency is slightly higher than the PVT collector without MWCNT. In addition, the highest maximum power increase is obtained when the $0.1 \mathrm{wt} \%$ MWCNT nanofluid is used as a coolant in the PVT collector.
\end{abstract}

Copyright $\odot 2019$ Institute of Advanced Engineering and Science. All rights reserved.

\section{Corresponding Author:}

Ahmad Fudholi,

Solar Energy Research Institute,

Universiti Kebangsaan Malaysia, 43600 Bangi Selangor, Malaysia.

Email: a.fudholi@ukm.edu.my

\section{INTRODUCTION}

Solar energy is renewable energy that can be produce thermal energy and electrical energy. Thermal energy can be obtained easily as long as there is sunshine using mediums (air and water). Both air and water absorbs heat from the thermal energy to be used in different fields. In terms of thermal energy from the hot water generated from solar energy can be used in hotels or inns, homes, hospitals, laundries and so on. Hotel and residential houses usually require hot water for bathing and drinking. Hospitals also need a lot of hot water for washing medical devices. Solar energy received at the Earth's surface can be divided into two types, namely photons for generating electricity and thermal energy. Apart from the energy use of petroleum for vehicles, electrical energy is energy which is very important in our lives today. Almost all daily activities in people's lives today require electricity. Thermal energy can also be used for air heating during winter, production of hot water for bathing and washing, cooking, drying and many more. Electrical energy can be generated using a photovoltaic (PV) solar collector. But the amount of electricity produced by PV solar collectors will decrease as a result of increased heat on PV cells in the solar collectors [1-13].

The photovoltaic (PV) is one of the technology used to harness solar energy. PV module from solar energy are widely adopted renewable energy sources and commercially available systems that can be used in various applications. However, the problem of temperature of PV module raising causes the efficiency to 
decerease was overcome by adding a heat recovery system to a PV module. Thus, photovoltaic thermal (PVT) collectors have been introduced to to produce electrical and thermal energy from solar energy simultaneously. A PVT collector typically comprises an PV module, absorber plate and a heat removal system. The PV module are usually attached to the absorber plate. PVT collectors have been developed in various systems over the past few years. However, new studies are still being conducted to improve system efficiency in terms of thermal and electrical aspects. Various studies have been conducted on PVT collectors based on air, water, air-water, and water-nanofuids as heat carriers. A water or nanofluid based PVT collector has similar structure as the conventional flat plate solar collectors. The absorber consist of tube is attached to the PV module in order to use for heating purposes. The water based PVT collector could achieve enhance cooling effectiveness compared to the air based system due to the high thermal mass of water over the air. Various theoretical and experimental studies of PVT collectors are available in the literature [14-21]. To overcome the limitation of conversion efficiency of PV cell, photovoltaic thermal (PVT) was introduced which is the most commonly used method for active cooling that provide both thermal and electricity simultaneously [22]. Beside that, by modifying the nonlinear I-V calculation which includes open circuit, extreme power and short circuit, the theoretical and simulation approach of the photovoltaic cell by Matlab-Simulink Situation can be evaluated to get a better performance [23, 24]. Zondag et al. [25] evaluated various designs of PVT water collector. The designs have categorised to sheet and tube, channel, free flow and two absorber. Although the sheet and tube design is indicated $2 \%$ less in efficiency than the channel design, it is the easiest design for manufacturing process. Thus, this design is the most promising compared to other designs.

Recently, various studies have been conducted PVT collectors based on water-nanofluids as heat carrier has been developed. Sardarabadi et al. [26] investigated experimentally the effects of silica/water nanofluids on thermal and electrical efficiency of PVT. The different concentration of nanofluid indicated that overal energy efficiency and total exergy increase with higher concentration of nanofluids. The efficiency PVT equipped with a collector compared with no collector show significantly higher perfomance. Zeinali et al. [27] investigated the convective heat transfer of nanofluids in laminar flow through a channel with a square-cross section resulted in increasing heat transfer when the size of nanoparticle is smaller and volume fraction is increased. Work have been largely carried out on nanofluid for the past decades. Experiments showed a significant increase for thermal conductivity by dispersion of less than $1 \%$ volume fraction of nanofluids. The ideal thermal properties of nanofluid with higher thermal conductivity and heat transfer, smaller and compact design of PVT will become possible without lessening the desired output. Yousefi et al. [28] investigated the efficiency of flat plate solar water heater collector by varying the mass flow rate and volume concentration of alumina nanofluid. The result drew that by increasing mass flow rate from 1 to $3 \mathrm{~L} / \mathrm{min}$, the efficiency of solar collector increased at a constant volume concentration. Jing et al. [29] prepare of highly dispersed $\mathrm{SiO}_{2} / \mathrm{H}_{2} \mathrm{O}$ with various particle sizes. They circulate the nanofluid both above the PV panel to filter IR part of the incident light and below the PV cell to remove the heat generated in the photoeletric conversion process. This design is helpful in reduce the operation temperature of PV cell and expected to improve PVT efficiency. Advantage of liquid filter is that they can be controlled dynamically by pumps, magnetic/electric field and temperature changes. $\mathrm{Xu}$ and Kleinstreuer [30] showed that concentration PVT using nanofluid is more suitable for silicon solar cell compared to multi junction solar cells and the overall energy conversion efficiency of the CPV/T system is higher than that of conventional system. Ghadiri et al. [31] evaluated the effect of ferrofluid as coolant on the overall efficiency of PVT. The results found that $50 \%$ increase in overall efficiency when ferrofluid was placed under alternating magnetic field with $50 \mathrm{~Hz}$ frequency.

Many experiment studies focused on the size, arrangement and type of fluid used for cooling in PVT collector, however studies using nanofluid as a coolant is still at an early stage. The use of nanofluid as heat transfer fluid in the PVT collector proved to result in better performance. This paper presents an experimental study to investigate the electrical characteristic of a PVT collector with and without Multiwalled Carbon Nanotube (MWCNT) nanofluid flow with spiral rectangular tube absorber.

\section{MATERIAL AND METHODS}

The setup of PVT collector during the indoor experiment under solar simulator is shown in Figure 1a. Spiral rectangular tube absorber (Figure1b) were selected in this study based on a study by Ibrahim et al. $[32,33$, Fudholi et al. [34] and Aisyah et al. [35]. The width of the absorber is $1.9 \mathrm{~cm} \times 1.9 \mathrm{~cm}$ with a thickness of $1 \mathrm{~mm}$. The improvement of the looser form of study is that the diameter of the absorber is raised to increase the touch surface area between the PV module and the absorber. The material used to make this absorber is rather than a rust-proof patient. The conductivity of the terminus is 16.3 to $20.0 \mathrm{~W} / \mathrm{mK}$. This material is chosen because of its cheaper price compared to copper and high calorific resistance. A standard 
polycrystalline $80 \mathrm{~W}$ PV module represented as a flat plate unglazed sheet attached on the top. The collector made up of single unilateral channel for the fluid to flow is inserted underneath the PV module. The size of PVT collector surface is $1.2 \mathrm{~m}$ long and 0.5 wide. K-type thermocouple used with data logger to collect the PV module surface temperature, inlet and outlet fluid. The change of temperature during the experiment can be tracked and recorded in 1 minute. The total incident radiation on the system is measured by pyranometer. A flow meter (1-4 G/M) mounted at the opening of fluid inlet for controlling of mass flow rate.

The experiment was conducted under indoor testing facility using solar simulator. The simulator consist of 40 halogen lamps and the intensity of solar radiation controlled by variable voltage controller. The PVT collector has been exposed to the solar radiation of $900 \mathrm{~W} / \mathrm{m}^{2}$ for 40 minutes before collecting data to ensure the equilibrium state of radiation. The change of voltage are recorded using electric load under different mass flow rate and volume concentration of nanofluid. The mass flow rate of water of $0.0255 \mathrm{~kg} / \mathrm{s}$. The temperature of the system collected from thermocouple stored in the ADAM Data Acquisition System for every 1 minute and later used to calculate the electrical and thermal efficiency for the collector. The water was circulated around the system using the pump and heat exchanger used for cooling the fluid in the cloosed loop system. The cooling fluid used in this experiments are water and water-MWCNT with 0.02 wt $\%$ and 0.1 wt\% concentration. MWCNT nanofluids are prepared with sonicator and added with stabilizer. The sonication process for dispersing nanoparticle in distilled water is about 1 hour. The zeta potential is used to examine the stability of nanofluid prepared. The properties of fluid used is shown in Table 1 . The electrical data collection for voltage, current, open circuit voltage $\left(\mathrm{V}_{\mathrm{oc}}\right)$ and short circuit current $\left(\mathrm{I}_{\mathrm{sc}}\right)$ uses an electronic load of 8500 model from BK Precision. The data obtained is used to plot the I-V curve graph. Maximum power $(\mathrm{Pm})$ can be determined from the graph.

Table 1. Fluid roperties

\begin{tabular}{ccccc}
\hline Fluid & Particle Size $(\mu \mathrm{m})$ & Heat Capacity $(\mathrm{J} / \mathrm{kgK}$ & Density $(\mathrm{kg} / \mathrm{m} 3)$ & Thermal Conductivity $(\mathrm{W} / \mathrm{mK})$ \\
\hline MWCNT/water & D:110-190 & 630 & 1700 & $\sim 3000$ \\
& L: $5-9$ & & & \\
\hline
\end{tabular}

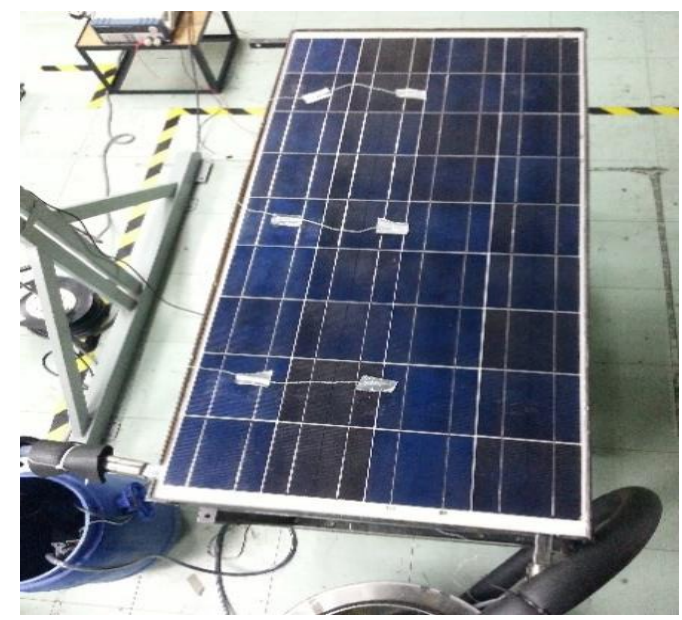

(a)

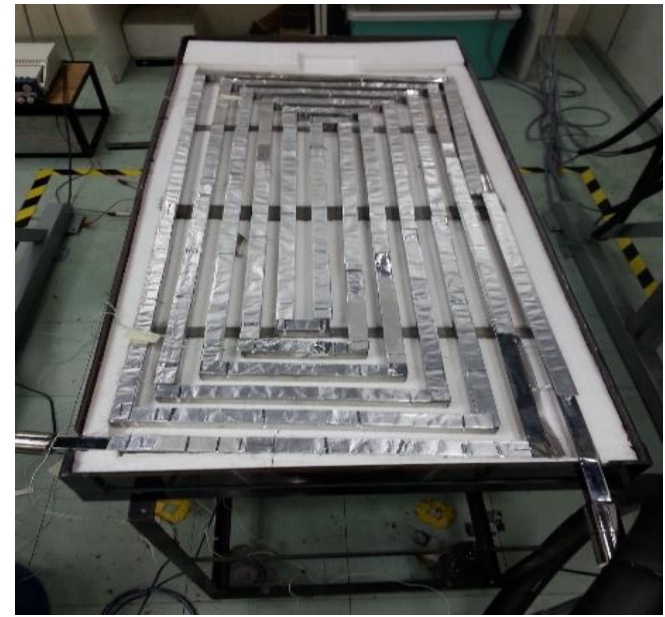

(b)

Figure 1(a). PVT water collector under solar simulator, (b) Spiral rectangular tube absorber attached at the PV back

The electrical efficiency of the PV module is measured by the maximum power ratio $\left(\mathrm{P}_{\mathrm{m}}\right)$ to the intended radiation,

$$
\eta_{p v}=\frac{P_{m}}{S A_{c}}
$$

where $A_{c}$ is the surface area of the collector, $S$ is the intensity of radiation, and $P_{m}$ is derived from the equation,

$$
P_{m}=V_{m} \times I_{m}
$$


The features of a PV module can be removed from the PV module output which can be explained by the resulting I-V curved nature of the curve. The curve changes as a function to the PV temperature $\left(\mathrm{T}_{\mathrm{pv}}\right)$ and the solar radiation $(\mathrm{S})$ received by the module.

The fill factor of a PV module is a measure of the real I-V characteristic curve. It defined as the maximum power ratio $\left(\mathrm{P}_{\mathrm{m}}\right)$ produced by the cell against the open circuit voltage product $\left(\mathrm{V}_{\mathrm{oc}}\right)$ and the closed circuit current $\left(\mathrm{I}_{\mathrm{sc}}\right)$. This fill factor $(\mathrm{FF})$ can be written as

$$
F F=\frac{P_{m}}{V_{o c} \times I_{s c}}
$$

The features of a PV module can be removed from the PV module output which can be explained by the resulting I-V curved nature of the curve. The curve changes as a function to the PV temperature $\left(T_{\mathrm{pv}}\right)$.

\section{RESULTS AND DISCUSSION}

PVT collector with and without MWCNT nanofluid has been tested in the laboratory. The effect of mass flow rate change on PVT collector without MWCNT nanofluid can be seen in Table 2. At the mass flow rate of $0.012 \mathrm{~kg} / \mathrm{s}$ and the solar radiation changed from $500 \mathrm{~W} / \mathrm{m}^{2}$ to $900 \mathrm{~W} / \mathrm{m}^{2}, \mathrm{I}_{\mathrm{sc}}$ increased from 0.841 A to $2.018 \mathrm{~A}$ and $\mathrm{V}_{\mathrm{oc}}$ decreased from $17.52 \mathrm{~V}$ to $17.00 \mathrm{~V}$. The resulting power also increased from $9.853 \mathrm{~W}$ to $22.823 \mathrm{~W}$ in the same solar radiation. The increase in the $\mathrm{I}_{\mathrm{sc}}$ and the decrease of $\mathrm{V}_{\mathrm{oc}}$ was recorded when the mass flow rate was changed to $0.0255 \mathrm{~kg} / \mathrm{s}$. When the maximum increase in power is recorded as $5.04 \%$, $4.36 \%$ and $3.32 \%$ at $500 \mathrm{~W} / \mathrm{m}^{2}, 700 \mathrm{~W} / \mathrm{m}^{2}$ and $900 \mathrm{~W} / \mathrm{m}^{2}$ at the same mass flow rate of $0.012 \mathrm{~kg} / \mathrm{s}$ and $0.0255 \mathrm{~kg} / \mathrm{s}$.

Table 2. Effect of solar radiation and mass flow rate on $\mathrm{V}_{\mathrm{oc}}$ and $\mathrm{I}_{\mathrm{sc}}$ of PVT collector

\begin{tabular}{|c|c|c|c|c|c|c|}
\hline \multirow{2}{*}{$\mathrm{S}\left(\mathrm{W} / \mathrm{m}^{2}\right)$} & \multicolumn{3}{|c|}{$\dot{\mathrm{m}}=0.012 \mathrm{~kg} / \mathrm{s}$} & \multicolumn{3}{|c|}{$\dot{\mathrm{m}}=0.0255 \mathrm{~kg} / \mathrm{s}$} \\
\hline & $\mathrm{I}_{\mathrm{sc}}(\mathrm{A})$ & $\mathrm{V}_{\mathrm{oc}}(\mathrm{V})$ & $\mathrm{P}_{\mathrm{m}}(\mathrm{W})$ & $\mathrm{I}_{\mathrm{sc}}(\mathrm{A})$ & $\mathrm{V}_{\mathrm{oc}}(\mathrm{V})$ & $\mathrm{P}_{\mathrm{m}}(\mathrm{W})$ \\
\hline 500 & 0.841 & 17.52 & 9.853 & 0.878 & 17.33 & 10.336 \\
\hline 700 & 1.360 & 17.35 & 16.029 & 1.424 & 17.05 & 16.728 \\
\hline 900 & 2.018 & 17.00 & 22.823 & 2.080 & 16.84 & 23.580 \\
\hline
\end{tabular}

After the PVT collector without MWCNT nanofluid test, the opimum mass flow rate determined is $0.0255 \mathrm{~kg} / \mathrm{s}$. PVT collector was studied with MWCNT nanofluids at different concentration $(0.02 \mathrm{wt} \%$ and $0.1 \mathrm{wt} \%$ ). Figure 2 to Figure 4 shows the I-V and P-V curves at the mass flow rate of $0.0255 \mathrm{~kg} / \mathrm{s}$ and the solar radiation of $500 \mathrm{~W} / \mathrm{m}^{2}$ to $900 \mathrm{~W} / \mathrm{m}^{2}$, and summarized in Table 3. For PVT collector without MWCNT nanofluid, $\mathrm{I}_{\mathrm{sc}}$ increases from 0.878 A to 2.080 A when the solar radiation changes from $500 \mathrm{~W} / \mathrm{m}^{2}$ to $900 \mathrm{~W} / \mathrm{m}^{2}$. When the PVT collector with $0.02 \mathrm{wt} \%$ MWCNT accumulates an increase from $0.912 \mathrm{~A}$ to $2,087 \mathrm{~A}$ in the same observation. At higher concentrations of MWCNT nanofluid, the $\mathrm{I}_{\mathrm{sc}}$ changed from 0.919 A to $2.154 \mathrm{~A}$.

Meanwhile, $\mathrm{V}_{\mathrm{oc}}$ for PVT collector without MWCNT nanofluid decreased from $17.43 \mathrm{~V}$ to $16.84 \mathrm{~V}$. The $\mathrm{V}_{\mathrm{oc}}$ change for the $0.02 \mathrm{wt} \%$ and $0.1 \mathrm{wt} \%$ MWCNT nanofuid, the $\mathrm{V}_{\mathrm{oc}}$ of collectors is $17.34 \mathrm{~V}$ to $16.92 \mathrm{~V}$ and $17.25 \mathrm{~V}$ to $16.82 \mathrm{~V}$, respectively. The displacement of the heat inside the nano bend is higher than water following the higher nanostructure of the nanostructures. Increased removal of higher heat will further reduce PV module temperature. The impression, an increase to the power of maximum and higher electrical impedance is listed.

Table 3. Effect of solar radiation and mass flow rate on $\mathrm{V}_{\mathrm{oc}}$ and $\mathrm{I}_{\mathrm{sc}}$ of PVT collector with and without

\begin{tabular}{ccccccc}
\multicolumn{9}{c}{ MWCNT nanoflid } \\
\hline $\mathrm{S}(\mathrm{W} / \mathrm{m} 2)$ & MWCNT & Isc (A) & Voc $(\mathrm{V})$ & Pm $(\mathrm{W})$ & FF & $\eta_{e l}(\%)$ \\
\hline 500 & Without & 0.878 & 17.43 & 10.336 & 0.679 & 3.32 \\
& $0.02 \mathrm{wt} \%$ & 0.912 & 17.34 & 10.645 & 0.673 & 3.42 \\
& $0.1 \mathrm{wt} \%$ & 0.919 & 17.25 & 10.780 & 0.680 & 3.47 \\
700 & Without & 1.424 & 17.25 & 16.728 & 0.689 & 3.68 \\
& $0.02 \mathrm{wt} \%$ & 1.456 & 17.21 & 16.823 & 0.679 & 3.70 \\
& $0.1 \mathrm{wt} \%$ & 1.464 & 17.13 & 17.041 & 0.684 & 3.75 \\
& Without & 2.080 & 16.84 & 23.580 & 0.673 & 4.01 \\
& $0.02 \mathrm{wt} \%$ & 2.087 & 16.92 & 23.754 & 0.678 & 4.02 \\
& $0.1 \mathrm{wt} \%$ & 2.154 & 16.82 & 23.790 & 0.665 & 4.05 \\
\hline
\end{tabular}




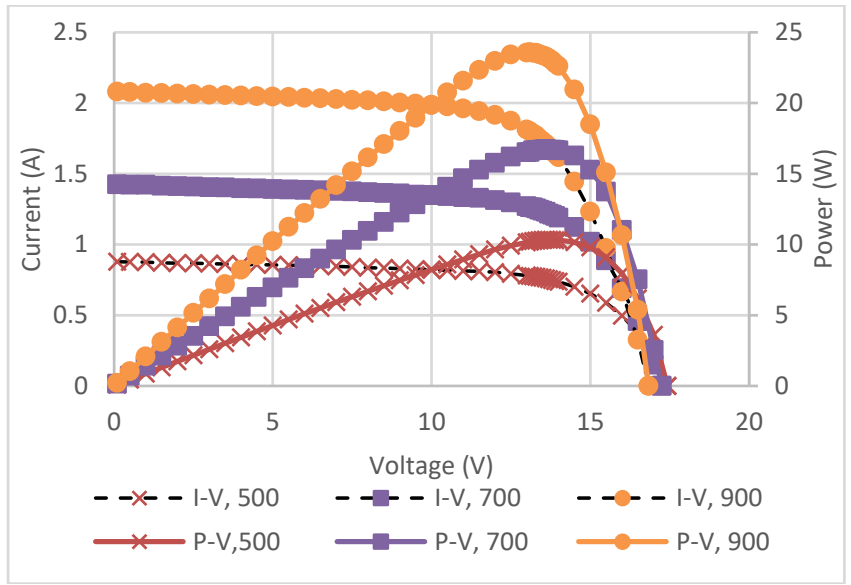

Figure 2. Power (P) and current (I) over voltage (V) for PVT collector without MWCNT at solar radiation of 500 to $900 \mathrm{~W} / \mathrm{m}^{2}$

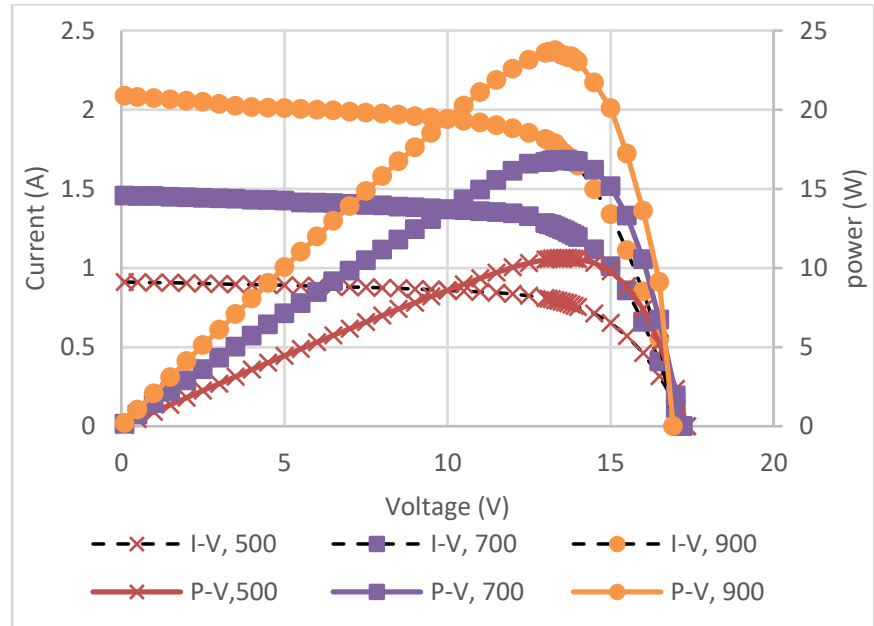

Figure 3. Power (P) and current (I) over voltage (V) for PVT collector with $0.02 \mathrm{wt} \%$ MWCNT nanofluid at solar radiation of 500 to $900 \mathrm{~W} / \mathrm{m}^{2}$

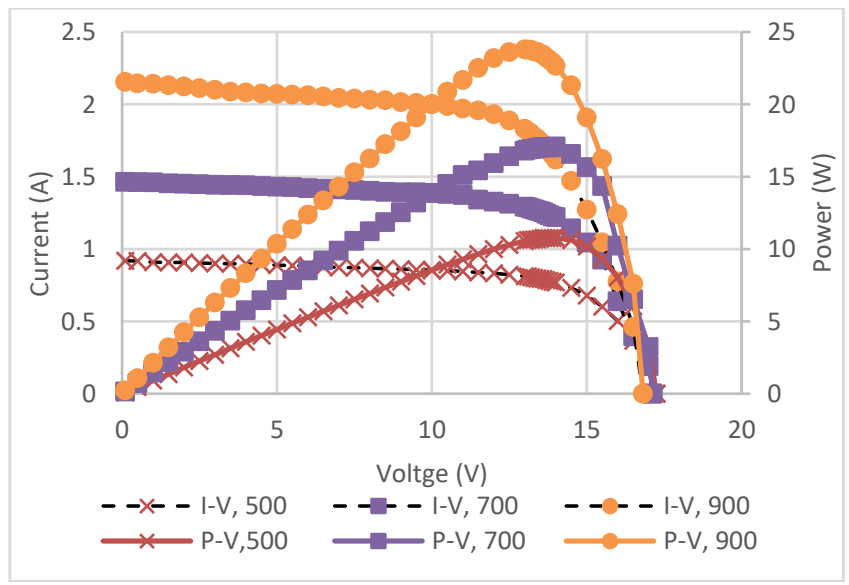

Figure 4. Power (P) and current (I) over voltage (V) for PVT collector with $0.1 \mathrm{wt} \%$ MWCNT nanofluid at solar radiation of 500 to $900 \mathrm{~W} / \mathrm{m}^{2}$ 


\section{CONCLUSION}

On the basis of present study, the results of these studies may be concluded as follow: 1) The highest maximum power increase is obtained when the $0.1 \mathrm{wt} \%$ MWCNT nanofluid is used as a coolant in the PVT collector. 2) The power generated will increase with the addition of solar radiation and efficiency is slightly higher than the PVT collector without MWCNT nanofluid.

\section{ACKNOWLEDGEMENT}

The authors would like to thank the Universiti Kebangsaan Malay-sia (UKM) for funding (GPK020448) and (GGP-2017-045), also Prof. Dr. Zahari Ibrahim for indoor testing in Physics Laboratory (Solar Simulator Lab.) and the Solar Energy Research Institute (SERI), UKM.

\section{REFERENCES}

[1] Budiyanto, Fadliondi (2018), The improvement of solar cell output power using cooling and reflection from mirror. International Journal of Power Electronics and Drive Systems (IJPEDS), 8 (3), 1320-26.

[2] Yahya M, Fudholi A, Hafizh H, Sopian K (2016), Comparison of solar dryer and solar-assisted heat pump dryer for cassava. Solar Energy 136, 606-13.

[3] Yahya M, Fudholi A, Sopian K (2017), Energy and exergy analyses of solar-assisted fluidized bed drying integrated with biomass furnace. Renewable Energy 105, 22-29.

[4] Fudholi A, Sopian K, Gabbasa M, Bakhtyar B, Yahya M, Ruslan MH, Mat S (2015), Techno-economic of solar drying systems with water based solar collectors in Malaysia: a review, Renewable and Sustainable Energy Review 2015; 51: 809-820.

[5] Fudholi A, Sopian K, Bakhtyar B, Gabbasa M, Othman MY, Ruslan MH (2015), Review of solar drying systems with air-based solar collectors in Malaysia. Renewable and Sustainable Energy Review 51, 1191-1204.

[6] Fudholi A, Sopian K, Ruslan MH, Alghoul MA, Sulaiman MY (2010), Review of solar dryers for agricultural and marine products. Renewable and Sustainable Energy Reviews 14(1), 1-30.

[7] Fudholi A, Sopian K, Alghoul MA, Ruslan MH, Othman MY (2015), Performances and improvement potential of solar drying system for palm oil fronds. Renewable Energy 78, 561-65.

[8] Fudholi A, Sopian K, Yazdi MH, Ruslan MH, Gabbasa M, Kazem HA (2014), Performance analysis of solar drying system for red chili. Solar Energy 99, 47-54.

[9] Fudholi A, Sopian K, Othman MY, Ruslan MH (2014), Energy and exergy analyses of solar drying system for red seaweed. Energy and Buildings 68, 121-29.

[10] Fudholi A, Othman MY, Ruslan MH, Sopian K (2013), Drying of Malaysian Capsicum annuum L. (red chili) dried by open and solar drying. International Journal of Photoenergy, 1-9.

[11] Fudholi A, Bakhtyar B, Saleh H, Ruslan MR, Othman MY \& Sopian K (2016), Drying of salted silver jewfish in a hybrid solar drying system and under open sun: modeling and performance analyses. International Journal of Green Energy 13 (11), 1135-1144.

[12] Fudholi A, Sopian K, Ruslan MH, Othman MY (2013), Performance and cost benefits analysis of double-pass solar collector with and without fins. Energy Conversion and Management 76, 8-19.

[13] Fudholi A, Sopian, K, Ruslan MH, Othman, MY, Bakhtyar, B (2013). Energy analysis and improvement potential of finned double-pass solar collector. Energy Conversion and Management 75, 234-40.

[14] Fudholi A, Zohri M, Jin GL, Ibrahim A, Yen CH, Othman MY, Ruslan MH, Sopian K (2018), Energy and exergy analyses of pho-tovoltaic thermal collector with $\nabla$-groove. Solar Energy 159, 742-50.

[15] Fudholi A, Sopian K (2018), R\&D of Photovoltaic Thermal (PVT) Systems: an overview. International Journal of Power Electronics and Drive Systems (IJPEDS) 9 (2), 803-10.

[16] Fudholi A, Sopian K (2018), Review on exergy and energy analysis of solar air heater. International Journal of Power Electronics and Drive Systems (IJPEDS) 9 (1), 420-26.

[17] Fudholi A, Sopian K (2018), Review on solar collector for agricultural produce. International Journal of Power Electronics and Drive Systems (IJPEDS) 9 (1), 414-19.

[18] Fudholi A, Haw LC, Sopian K \& Abdulmula AMO (2018), Primary study of tracking photovoltaic system for mobile station in Malaysia. International Journal of Power Electronics and Drive Systems (IJPEDS) 9 (1), 427-32.

[19] Zohri M, Nurato N, Fudholi A (2017), Photovoltaic thermal (PVT) system with and without fins Collector: Theoretical Approach. International Journal of Power Electronics and Drive System (IJPEDS) 8(4), 1756-63.

[20] Zohri M, Bakti LD, Fudholi A (2018), Exergy assessment of photovoltaic thermal with v-groove collector using theoretical study. TELKOMNIKA 16(2), 550-57.

[21] Nazri NS, Fudholi A, Bakhtyar B, Yen CH, Ibrahim A, Ruslan MH, Mat S, Sopian K. (2018), Energy economic analysis of photovoltaic-thermal-thermoelectric (PVT-TE) air collectors. Renewable and Sustainable Energy Review 92, 187-97.

[22] Nazri NS, Fudholi A, Ruslan MH, Sopian K. (2018), Mathematical modeling of photovoltaic thermalthermoelectric (PVT-TE) air collector. International Journal of Power Electronics and Drive Systems (IJPEDS), 9 (2), 795-802.

[23] Kumari JS \& Babu CS (2012), Mathematical Modeling and Simulation of Photovoltaic Cell using MatlabSimulink Environment, International Journal of Electrical and Computer Engineering (IJECE), 2 (1), 26-34. 
[24] Mohamed MAEH (2017), The Linear Model of a PV module", International Journal of Power Electronics and Drive System (IJPEDS), 8 (2), 900-906.

[25] Zondag HA, de Vries DW, van Helden WGJ, van Zolingen RJC, van Steenhoven AA (2003), The yield of different combined PV-thermal collector designs. Solar Energy 74, 253-269, 2003.

[26] Sardarabadi M, Passandideh-Fard M, Heris SZ (2014), Experimental investigation of the effects of silica/ water nanofluid on PV/T (pho-tovoltaic thermal units). Energy 66, 264-72.

[27] Heris SZ, Kazemi-Beydokhti A, Noie SH, Rezvan S (2012), Numerical study on convective heat transfer of $\mathrm{Al}_{2} \mathrm{O}_{3} /$ water, $\mathrm{CuO} /$ water and $\mathrm{Cu}$ /water nanofluids through square cross-section duct on laminar flow. Engineering Appications of Computational Fluid Mechanics 6, 1-14.

[28] Yousefi T, Veysi F, Shojaeizadeh E, Zinadini S (2012), An experimental investigation on the effect of Al2O3-H2O nanofluid on the efficiency of flat-plate solar collectors, Renewable Energy 39 (1) 293-98.

[29] Jing D, Hu Y,Liu M, Wei J, Guo L (2015), Preparation of highly dispersed nanofluid and CFD study of its utilization in a concentrating PV/T system. Solar Energy 112, 30-40.

[30] Xu Z, Kleinstreuer C (2014), Concetration photovoltaic-thermal energy co-generation system using nanofluids for cooling and heat-ing. Energy Conversion and Management 87, 504-12.

[31] Ghadiri M, Sardarabadi M, Pasandideh-fard M, Moghadam AJ (2015), Experimental investigation of a PVT systems performance using nano ferrofluids. Energy Conversion and Management 103, 468-76.

[32] Ibrahim A, Jin GL, Daghigh R, Mohamed Salleh MH, Othman, MY, Ruslan MH, Mat S, Sopian K (2009). Hybrid photovoltaic thermal (PV/T) air and water based collectors suitable for building integrated applications. American Journal of Environmental Sciences 5(5), 618-24.

[33] Ibrahim A, Fudholi A, Sopian, K, Othman, MY, Ruslan MH (2014). Efficiencies and improvement potential of building integrat-ed photovoltaic thermal (BIPVT) system, Energy Conversion and Management 77, 527-34.

[34] Fudholi A, Sopian K, Yazdi MH, Ruslan MH, Ibrahim A \& Kazem HA (2014), Performance analysis of photovoltaic thermal (PVT) water collectors. Energy Conversion and Management 78, 641-51.

[35] Aisyah CN, Fudholi A, Othman, MY, Ibrahim A, Ruslan MH, Sopian, K, (2018). Kecekapan pengumpul PV/T menggunakan pengumpul terma reka bentuk pilin (Efficiency of PV/T collector using spiral thermal absorber design), Sains Malaysiana 47 (4), 853-859. 